\title{
Exceptionality Education International
}

Volume 30

Issue 2 Intersectionalities in Leadership

Conference

$9-1-2020$

\section{Cases Inquiry as Critical Praxis: Supporting Intersectionality Within Inclusive Leadership Practices}

Jhonel Morvan

Brock University, jhonel.morvan@brocku.ca

Déirdre M. Smith Ms.

Ontario College of Teachers, dsmith@oct.ca

ISSN 1918-5227

Pages 80- 95

\section{Recommended Citation}

Morvan, J., \& Smith, D. M. (2020) Cases Inquiry as Critical Praxis: Supporting Intersectionality

Within Inclusive Leadership Practices. Exceptionality Education International, 30, 80-95. 


\title{
Cases Inquiry as Critical Praxis: Supporting Intersectionality Within Inclusive Leadership Practices
}

\begin{abstract}
This article illuminates the significance of exploring intersectionalities within inclusive leadership practices through case inquiry as a critical praxis. Five educational institutions engaged in a partnership focused on exploring the lived practices and professional knowledge of school leaders as they worked towards supporting a vision of inclusive education within their individual school communities. These lived experiences were represented in written cases that have been captured in a provincial resource, Exploring Inclusive Leadership Practices through Case Inquiry (Sider, Maich, Morvan, Specht, \& Smith, 2018).

Mobilizing the knowledge and practices within this resource and supporting exploration of this knowledge and associated practices through a lens of critical praxis has been one of the key knowledge mobilization components of the June 1, 2019 conference, Exploring Intersectionalities for Leadership and School Inclusion, held at the University of British Columbia. This knowledge mobilization event, along with other initiatives, such as the case resource, helped to foster critical dialogue and interrogation related to leadership practices that can support or hinder a vision and enactment of inclusive education within school communities.
\end{abstract}

\section{Keywords}

Case inquiry, case studies, intersectionalities, inclusive school leadership, professional learning, the leadership development

\section{Creative Commons License}

c) (7) (8)

This work is licensed under a Creative Commons Attribution-Noncommercial 4.0 License 


\title{
Cases Inquiry as Critical Praxis: Supporting Intersectionality Within Inclusive Leadership Practices
}

\author{
Jhonel Morvan \\ Brock University \\ Déirdre M. Smith \\ Ontario College of Teachers
}

\begin{abstract}
This article illuminates the significance of exploring intersectionalities within inclusive leadership practices through case inquiry as a critical praxis. Five educational institutions engaged in a partnership focused on exploring the lived practices and professional knowledge of school leaders as they worked toward supporting a vision of inclusive education within their individual school communities. These lived experiences were represented in written cases that have been captured in a provincial resource, Exploring Leadership Practices Through Case Inquiry (Sider, Maich, Morvan, Specht, \& Smith, 2018). Mobilizing the knowledge and practices within this resource and supporting exploration of this knowledge and associated practices through a lens of critical praxis has been one of the key knowledge mobilization components of the June 1, 2019, conference, Exploring Intersectionalities for Leadership and School Inclusion, held at the University of British Columbia. This knowledge mobilization event, along with other initiatives, such as the case resource, helped to foster critical dialogue and interrogation related to leadership practices that can support or hinder a vision and enactment of inclusive education within school communities.
\end{abstract}

This article is a case report that argues in favour of case inquiry (Smith \& Goldblatt, 2009; Goldblatt \& Smith, 2004, 2005) as the most appropriate method for targeted professional learning aiming at addressing intersectional issues of education. It is based on a provincial case resource and a major national conference event, both of which resulted from a research project focused on how school principals can support the 
inclusion of students with special education needs. The following sections describe in detail these two knowledge mobilization efforts which constitute the heart of this article.

Knowledge mobilization "refers to the movement of research into active use with knowledge users in order to help facilitate the uptake of research findings, partnerships and impacts around practice, policy and behaviour change" (Brock University, n.d.). Knowledge mobilization processes for advancing leadership development related to intersectionality and inclusive education among teacher leaders and school principals has been a key focus of a joint partnership involving five educational institutions that are currently involved in initial teacher education, continuing teacher education, and the professional learning of school leaders. Knowledge mobilization focuses on processes to disseminate, share, implement, build capacity, and bring to the fore actions, insights, and knowledge to influence various aspects of educational practices and policies (Ontario Education Research Panel, n.d.). A case resource, Exploring Leadership Practices Through Case Inquiry (Sider, Maich, Morvan, Specht, \& Smith, 2018), was developed from this provincial partnership. This resource, a compilation of eight contextual and real-life cases, has become a central professional learning tool for mobilizing the professional knowledge and actions of practitioners who were part of this inclusive leadership project.

Intersectional knowledge is a central dimension of the case resource (Sider et al., 2018). This resource was collaboratively developed with practising school leaders as a result of a joint inquiry into their lived experiences as they worked to support inclusive education. School leaders who are committed to fostering inclusive learning environments for all learners must be aware of and address the "complex social inequalities, a social location that predisposes them to respond to intersectionality as critical praxis" (Collins, 2015, p. 15). Intersectionality, as a critical praxis, illuminates a path toward socially just and antioppressive inclusive educational practices and policies. This form of praxis also illuminates the ethical stances, professional knowledge, and commitments required of school leaders who collaboratively work toward this vision of emancipatory inclusive education. The case resource (Sider et al., 2018) was designed to support this form of critical praxis.

The June 1, 2019, conference, Exploring Intersectionalities for Leadership and School Inclusion, held at the University of British Columbia served as another forum for knowledge mobilization for the case resource. The conference, as a forum for critical inquiry and dialogue, helped to illustrate why intersectionalities and case studies are two important themes in conversations regarding professional learning for education professionals. The main theme of the session was "Intersectionalities in leadership for supporting students with special education needs in Canadian schools". While the conference aimed at bringing scholars, Indigenous educators, school system administrators, and representatives of government ministries and professional education associations together to consider how school principals can support the inclusion of students with special education needs, participants brought up many other themes that intersect with the overall goal. Among them, they raised issues regarding deconstructing or confronting otherness; acknowledging, understanding and exploring privilege; building collaborative communities; teaching teachers about inclusion; and using case studies to approach students holistically. The event placed the spotlight on the need for more targeted professional learning using case studies as a more appropriate method to approach the intersectional issues in education. 
The following paragraphs delineate case inquiry as a learning process and critical approach that invites interrogation of power, status quo, and systems. The inquiry method provides leadership development with opportunities to deal with the ethical challenges and dilemmas of practice in less threatening ways. Through a collection of written cases, sets of complex school problems, conflicts, disagreements, and challenges are critically explored through the adoption of an inquiry stance as a way to promote professional learning. Next, the section on cases as tools for professional learning serves as a springboard to the complex world of intersectionality that allows considerations for the multiple interactions among socio-demographic factors and other characteristics of individuals, groups, and systems. All these pieces come together at the end when collaborative inquiry and knowledge mobilization arguably seem to be the preferred ways to approach professional learning while attending to the intersectional nature of educational issues, including those related to students with special education needs.

\section{Case Inquiry for Leadership Development}

Traditionally, most leadership development models tend to be based on training involving university coursework and practicum. The complex realities of schools require approaches and models that are multifaceted and more appropriate for dealing with educational challenges and dilemmas. Case inquiry has emerged as a powerful andragogical and professional learning process for fostering leadership and teacher development within the field of education (Fossey \& Crow, 2011; Goldblatt \& Smith, 2004, 2005; Griffiths \& Ryan, 2018; Maich, 2015; Maich \& Hill, 2017; Shulman, 1992; Shulman \& Colbert, 1988; Shulman, Whittaker \& Lew, 2002; Smith, 2015a, 2015b). A critical approach to case inquiry facilitates deep exploration of the assumptions, beliefs, and biases that underpin the actions and decisions of education professionals. This form of critical professional inquiry also invites interrogation of the presence of power, colonization, and oppression that exist within educational policies, systems, structures, and practices. Analyzing ethical challenges and dilemmas of practice through critical case inquiry enables "the explication of professional knowledge, judgement and practice to be made visible, articulated and then collectively scrutinized" (Smith, Kelly, \& Allard, 2016, p. 10). This process of analysis can help inform and transform professional practice.

Case inquiry in education is grounded in the real-life contexts, experiences, and ethical challenges of educators and can reveal the complex dilemma-based nature of professional practice. These revelations and illuminations serve as rich sources of professional investigation and professional learning. Case inquiry also integrates intersectionality as a critical practice (Gonzalez \& Collins, 2019), which can serve to deepen understanding and support a critical, inclusive, and anti-oppressive stance within leadership and teaching practices. Rich cases can be entered into from multiple perspectives and can offer a lens into the multilayered meaning-making processes that are integrated within educational leadership and teaching practices.

The case inquiry processes employed within this collaborative leadership project focused on inclusive education and were rooted in the critical case approaches employed by Canadian educators (Porter \& Smith, 2011; Smith, 2015a, 2015b; Smith \& Goldblatt, 2009; Smith et al., 2016). The tenets of critical pedagogy underpin this critical approach to case inquiry (Apple, 2013; Darder, 2014; Freire, 1970; Giroux 1992; Kincheloe, 2008; 
McLaren, 1998). This critical approach to case inquiry is also informed and extended through decolonizing methodologies (Archibald, 2008; Battiste, 2013; Denzin, Lincoln, \& Smith, 2008; Smith, 1999), engaged critical pedagogy (hooks, 1994, 2004) and the key dimensions inherent within ethical educational leadership (Branson \& Gross, 2014; Starratt, 2004). Starratt (2009) articulated the rich value of case inquiry for informing professional practice and policy when he wrote:

Case studies, therefore, provide opportunities to engage in the drama of school problems, conflicts, disagreements and challenges in a safe learning environment where the players in the drams can adopt the role of the protagonists, discuss with others their perceptions of the problem or issue, and explore several alternative responses and their probable consequences. Through the multiple rehearsals of the messy drama of everyday life in schools, educators can develop greater professional flexibility and adaptability in their responses, can become more reflective about the assumptions they and others bring to conflict situations, can develop deeper sense of compassions toward propensity to unintentionally create messes, can clarify the core values they will stand by, can explore policy issues behind decisions, and finally, can grow in their capacity to deal with the shortterm symptoms of problems while looking toward the more effective long-range preventative measures required to forestall similar problems in the future. (p. xviii)

\section{Case Inquiry as a Tool for Professional Learning}

Practitioners have complained that traditional approaches to training school leaders, including university coursework and teaching and practicum, have not been very satisfactory. Many deficiencies are identified in training and professional development programs. Consequently, professional learning opportunities have been offered in various alternative forms including reading groups, co-teaching, co-planning, reflexive practice sessions, and collaborative inquiry. Cases are sound forms of educational models because of their propensity to allow for analysis of real life and authentic situations. Maich (2015) argued that case studies have "a rich, strong history as an effective, engaging, studentcentred instructional strategy to supplement more traditional approaches to knowledge transmission" (p. xiv).

As educational issues have become more and more complex and multifaceted, and as student populations have become more and more diverse, there is a growing need to use tools that bring information to life for multiple learners in a real-world, practical manner (Foran, 2001; Hackney, McMaster, \& Harris, 2003). Case inquiry is one of these tools and is very appropriate for the intersectional aspects of current issues in education. Garcia and Ortiz (2013) captured that idea of intersectionality very well when they wrote:

For example, while a disability label may assign students to a subordinate status in a general education classroom on the basis of their perceived disabilities, their gender, social class and/or racial identities may mitigate this status in different ways, creating privilege for some (e.g., male, middle class, or Caucasian students) but disadvantage for others (e.g., African American males from low income families). (p. 34)

According to Stanford University (1994), the case methodology covers a wide range of problematic situations posed for consideration, and they usually include some fundamental characteristics: contextual, complex, ambiguous, and relevant. Stanford University argued that cases are typically based on real events or are a series of likely 
events which could reasonably take place in a given context. They often cast a story, one that involves complexity and ambiguity that need to be resolved. It is important to make clear that most case studies do not allow for one obvious or clear solution. In summary, the case study itself might be complex or simple but it is, after all, a story of people portraying difficult situations that requires a decision to be made in order for certain results to be obtained. Fossey and Crowe (2011) agreed that "although no two cases are alike in terms of their narrative structure and pedagogical style, ... that all good teaching cases include these four elements: context, complexity, ambiguity, and relevance" (p. 5-6).

Historically, case teaching was introduced as a pedagogy by the dean of the Harvard Law School, Christopher Columbus Langdell, in the late 1800s. Scholars agree that Langdell revolutionized legal education when he instituted case teaching at Harvard Law School. Years later, scholars have developed case books for classes in educational administration and other education contexts. Barnes, Christensen, \& Hansen (1994) admitted that "a good case is the vehicle by which a chunk of reality is brought into the classroom to be worked over by the class and the instructor. A good case keeps the class discussion grounded upon some of the stubborn facts that must be faced in real life situations" (p. 44).

\section{Addressing Special Education Needs and Intersectionalities Through Case Inquiry}

Over the years, case studies have grown in popularity not only for teachers' pre-service education, but also because they offer great opportunity for in-service professional learning. They have been used, often, in professional learning communities to support teachers' ongoing learning (Watson, 2014). They have also been particularly helpful in supporting learning about special education (Calder Stegemann \& AuCoin, 2017; Maich \& Hill, 2017). They offer the advantage that they can happen on the job, are relevant and contextual, lend themselves well to intersectionalities, favour collaboration between colleagues, and appear less intimidating for staff. Whether case studies are fictional, authentic, or inspired by reallife situations, they demonstrate and dramatize humanity and its stories, conflicts, issues, and complexities in an easily accessible way (Davis \& Wilcox, 2003; Parker, Smith, \& Goldblatt, 2009). Their open-ended nature and authentic feel provide learners with the opportunity to discuss, debate, probe, role-play, evaluate, prioritize, critique, synthesize, while comparing facts, issues, and dilemmas (Barroso \& Abreu, 2015; Foran, 2001).

There has been, however, limited use of cases to examine situations involving children with less visible issues such as learning, intellectual, mental health, and developmental disabilities - whether labelled or implied. Cases would be particularly helpful in this area due to the complex issues implicated and the multiple stakeholders involved (Simplican, Leader, Kosciulek, \& Leahy, 2015). Additionally, case inquiry offers great avenues for discussions on situations involving gender identity and race, two other areas people may be very uncomfortable addressing. Case inquiry is an effective tool for informing professional learning and for addressing intersectionalities. Garcia and Ortiz (2013) argued that "intersectionality makes possible the examination of the simultaneous interactions among race, class, gender, and (dis)ability for any individual child, family and community, as well as the interplay between these individual or group characteristics and organizational responses to them" (p. 34). 
It is well documented that cases have also been used in the professional learning of school principals (e.g., Gardiner \& Tenuto, 2015; Griffiths \& Ryan, 2018; Hanhimäki \& Tirri, 2009; Sider, Maich, \& Morvan, 2017; Wettlaufer \& Sider, 2019). Those responsible for the professional learning of principals have found that case studies support reflective practices for educators, particularly on issues related to ethical dilemmas and social justice (Gardiner \& Tenuto, 2015; Hanhimäki \& Tirri, 2009). Cases that are situated around a particular "disorienting dilemma" (Mezirow \& Taylor, 2009) or "critical incident" (Yamamoto, Gardiner, \& Tenuto, 2013) provide opportunities for principals to consider their own practices in relation to such cases.

Despite the benefits of cases as a learning tool for principals, they have been used only minimally in the professional learning programs of principals and other education professionals, specifically in the context of students with disabilities (Griffiths \& Ryan, 2018; Sider et al., 2017). This is surprising, considering the complex and interconnecting issues that are present with students with neuro-developmental disabilities and the resulting implications for school principals. Research and knowledge mobilization projects are underway to address the limited number of cases that are written for the intersection of school leadership and special education, particularly for complex disabilities and interconnecting issues.

The two major outcomes of the project leading to this article are the case resource booklet (Sider et al., 2018) and the June 1st conference, Exploring Intersectionalities for Leadership and School Inclusion, at the University of British Columbia. Both of these components contribute significantly to knowledge mobilization initiatives related to inclusive leadership practices as well as to issues related to students with special education needs. The following two sections detail the importance of cases in the research project and give an overview of the knowledge mobilization approaches used to fill the gap in terms of the limited number of cases written on the intersectional aspects of school leadership and special education.

\section{Role of Cases in Our Collaborative Leadership Project}

As mentioned in the introduction, this collaborative leadership project involved the partnership of staff from five different educational institutions interested in facilitating the development of a provincial resource, Exploring Inclusive Leadership Practices Through Case Inquiry (Sider et al., 2018), designed to foster critical inquiry into the practices of school principals who are working toward supporting inclusive educational practices. The impact of this project was almost instantaneous. Since its creation, this leadership case resource has been used in initial teacher education, in continuing teacher education, and in principals' development courses to deepen professional inquiry and reflection into the many dimensions associated with creating inclusive learning contexts for all.

Sider et al. (2018) is a resource comprised of a collection of cases depicting the lived experiences of school principals. Each case illuminates various practices, challenges, and complexities associated with fostering cultures of inclusion within the context of individual school communities. A set of inquiry questions follows each case, which invites deeper exploration of the lived experiences of the school principals. Experienced educators and facilitators of courses for school principals offer a case commentary for each case. The commentaries provide alternative lenses for thinking about the case. 
Readers are invited, through the commentaries, to re-examine the case scenarios from different perspectives and viewpoints, thus extending their understanding of the complexities inherent within each case.

\section{Inclusive Leadership Concepts and Themes}

The cases included in the case resource illuminated many concepts and themes associated with inclusive educational practices and intersectionality, as shown in Figure 1.

Figure 1. Concepts and Themes Associated with Inclusive Educational Practices and Intersectionality

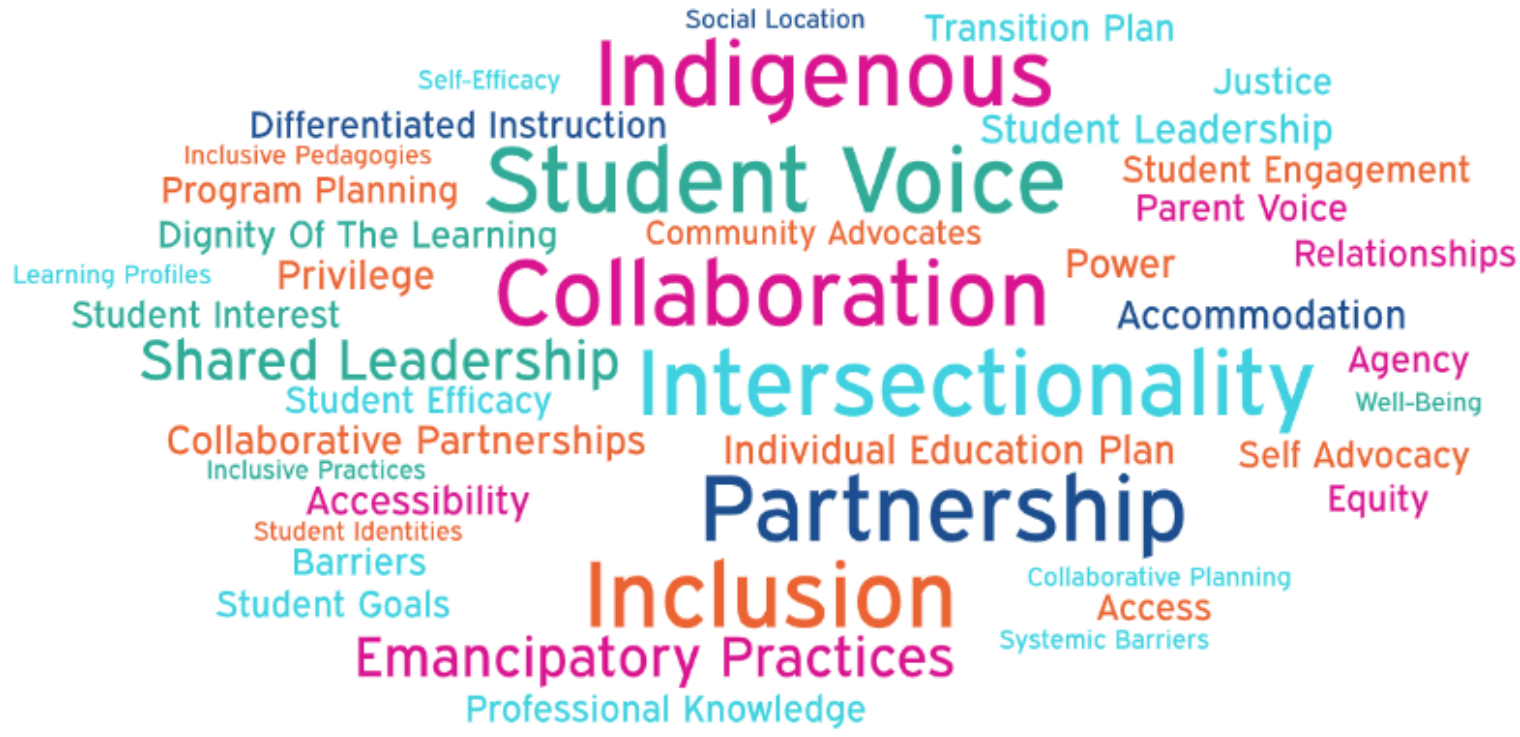

Educational leaders were invited to critically examine these concepts and themes and the implications of these themes for professional practice and policy when engaging in case inquiry through using the resource (i.e., Sider et al., 2018).

\section{Knowledge Mobilization Approaches}

This section identifies the different processes employed to advance and mobilize knowledge related to the case resource booklet and related leadership practices associated with inclusion. This provincial teacher education and leadership case resource illuminated the intersectionalities within inclusive leadership practices. It also supported examination of the professional knowledge needed to respond to complex issues in education through critical reflection and case inquiry. A variety of knowledge mobilization approaches were employed to support access to, knowledge of and use of the case resource within initial and continuing teacher education as well as professional practice. The resource was promoted at various educational conferences (Table 1), research forums, through published research articles, and within teacher education and leadership development programs. 
Table 1

Knowledge Mobilization-Educational Conferences

\begin{tabular}{ll}
\hline \multicolumn{1}{c}{ Conferences \& Forums } & Knowledge Mobilization Process \\
\hline Canadian Research Centre on Inclusive Education & $\begin{array}{l}\text { Resource was published on } \\
\text { website and was downloadable }\end{array}$ \\
$\begin{array}{l}\text { Intersectionalities in leadership for supporting students with } \\
\text { special education needs in Canadian schools, University of } \\
\text { British Columbia }\end{array}$ & $\begin{array}{l}\text { Resource highlighted and links } \\
\text { provided }\end{array}$ \\
$\begin{array}{l}\text { CEC-DADD on Autism, Intellectual Disability, and } \\
\text { Developmental Disabilities (January 15-18, 2019) - Hawaii }\end{array}$ & Copies of resource made available \\
$\begin{array}{l}\text { PREVNet Conference (May 14-15, 2019) - Toronto } \\
\text { Queen's University Conference }\end{array}$ & $\begin{array}{l}\text { Copies of resource made available } \\
\text { Copies of resource made available }\end{array}$ \\
\hline
\end{tabular}

The resource was also widely distributed in both the English language and French language and available through several open-access online websites. In the province of Ontario, every principal, all directors of education, educational organizations, and Indigenous organizations involved in principal professional learning received a digital or hard copy of the resource. The specific knowledge mobilization strategies that were employed for distribution (Table 2) of this leadership case resource in Ontario were diverse and varied.

Integrating the resource within continuing education. The provincial case resource (Sider et al., 2018) has been used to support inclusive education within the context of many continuing teacher and leadership development courses that currently exist for educators in Ontario. The cases in this resource support the stances and course concepts outlined in many of these continuing education courses for educators. The use of this case resource within the various provincial courses focused on educational leadership supports critical exploration of inclusive leadership practices. Table 3 provides examples of the various stances and course concepts associated with inclusive education, intersectionality, and anti-oppression that are currently included in continuing education courses for Ontario educators. These stances and concepts embedded within these courses align with the concepts and themes explored in the case resource (Sider et al., 2018) and support critical praxis. Continuing teacher education course designers and instructors are encouraged to use the resource as an andragogical tool within these leadership courses.

The various knowledge mobilization processes that have been employed were designed to support exploration and interrogation into the critical praxis needed to ensure educational spaces that are truly inclusive, just, and emancipatory. The table group discussions at the June, 2019 conference, Exploring Intersectionalities for Leadership and School Inclusion, confirmed and reiterated that fact. The context of continuing teacher education courses offers particularly powerful venues for facilitating critical dialogue and inquiry into inclusive education, intersectionality and anti-oppression. The use of the case resource (Sider et al., 2018), which was very well received at the conference and other knowledge mobilization events, becomes a central tool within leadership courses. The case resource aligns with the critical praxis concepts that are to be explored within the courses and professional learning sessions. 
Table 2

Knowledge Mobilization-Distribution of the Resources

\section{Educational Partner}

Continuing Teacher Education Providers

District School Boards

60 English Language Boards

12 French Language Boards

10 School Authorities

Academic Subject Associations

Deans of Education

Continuing Teacher Education Course

Providers

Provincial Principal Organizations

Supervisory Officer Organizations

Teacher Federations

L'Association des enseignantes et des enseignants franco-ontariens

Matawa First Nations Management

Métis Nation of Ontario

M'Chigeeng First Nation

Educative Sessions for Additional Qualification Course Designers and Facilitators

Ontario Ministry of Education

Canadian Society for the Deaf

School Principals

Open Space Consultation for Kindergarten

Individual requests (from educators)

Educational conferences

Six Nations Polytechnic

Chiefs of Ontario

Principal Qualification Programs

Regulatory bodies

Ontario College of Teachers Website

Ontario College of Teachers Standards of

Practice and Education Committee

\section{Knowledge Mobilization Process}

Resource was emailed to all providers -50 copies; resource was also published on Ontario College of Teachers website and was downloadable

Electronic distributed to Directors of Education 82 copies

Electronic distribution -116 copies
Electronical distribution -19 copies

Hard copy distribution to Additional

Qualification course providers - 43 copies

Electronic and hard copy distribution -100 copies

Electronic distribution - 5 copies

Electronic distribution -3 copies

Electronic distribution -1 copy

Electronic distribution -1 copy

Electronic distribution -1 copy

Electronic distribution -1 copy

Hard copy distribution -150 copies

Electronic distribution -10 copies

Electronic distribution -1 copy

Electronic and hard copy distribution - 5715 copies

Hard copy distribution - 68 copies

Electronic and hard copy distribution -150 copies

Hard copy distribution -15 copies

Electronic distribution -1 copy

Electronic distribution -1 copy

Electronic and hard copy distribution -525

copies

Electronic distribution -10 copies

Link www.oct.ca

Hard copy distribution -10 copies 
Table 2, continued

\section{Educational Partner}

Ontario College of Teachers Social Media

(Facebook, Twitter, LinkedIn, Instagram)

Ontario College of Teachers Additional

Qualification Extranet Site

Ontario College of Teachers Additional

Qualification Newsletter

Ontario College of Teachers Professionally

Speaking Article

\section{Knowledge Mobilization Process}

Electronic posts - 20

Electronic PDF file

Electronic copies - 50

Hard copy distribution - 300,000

Electronic posting on website www.oct.ca

Table 3

Knowledge Mobilization: Integration into Continuing Education Courses

\section{Continuing \\ Education}

Leadership

Courses for

Educators

Principal's

Qualification

Program

Guideline
Course Stance /

- Course Concepts

Critical Theoretical Framework

The adoption of a critical pedagogical lens and an inquiry stance are theoretical underpinnings of the Principal's Qualification Program. Course candidates will be invited throughout the course to engage in critical reflection as they explore a variety of leadership theories central to creating and sustaining ethical, equitable, just, inclusive, engaging and empowering learning environments.

- Critically examines one's individual leadership stance through the lenses of equity, ethics, inclusion, privilege, power, anti-oppressive practices, and democratic dialogue

- Critically explore the intersectionality between one's leadership stance, leadership identity, leadership resources, and professional context

- Collectively design and integrate holistic, inclusive education practices that examine diversity, access, equity, advocacy and anti-oppressive frameworks

- Create and sustain safe, inclusive, and ethical spaces for the inclusion of all student's voice and leadership

- Explore strategies to privilege and connect the lived experiences of students, families, caregivers, and staff to inform teaching and learning

- Foster a culture committed to implementing differentiated instruction, Universal Design, experiential learning, and critical pedagogy supporting the education of all students
Number of

Candidates

(2018)

1,923 
Table 3, continued

\begin{tabular}{|c|c|c|}
\hline $\begin{array}{l}\text { Continuing } \\
\text { Education } \\
\text { Leadership } \\
\text { Courses for } \\
\text { Educators } \\
\end{array}$ & $\begin{array}{l}\text { Course Stance I } \\
\text { - Course Concepts }\end{array}$ & $\begin{array}{l}\text { Number of } \\
\text { Candidates } \\
\text { (2018) }\end{array}$ \\
\hline \multirow[t]{5}{*}{$\begin{array}{l}\text { Supervisory } \\
\text { Officer's } \\
\text { Qualification } \\
\text { Guideline }\end{array}$} & $\begin{array}{l}\text { Supervisory Officers play a crucial role in establishing and } \\
\text { sustaining system practices and procedures for school and } \\
\text { system leaders in order to support an equitable and inclusive } \\
\text { education system. }\end{array}$ & 99 \\
\hline & $\begin{array}{l}\text { - Developing and sustaining learning communities that } \\
\text { support equitable and inclusive education }\end{array}$ & \\
\hline & $\begin{array}{l}\text { - Leading inclusive, flexible, and equitable program designs } \\
\text { that incorporate the voice, leadership, and engagement of all } \\
\text { students }\end{array}$ & \\
\hline & $\begin{array}{l}\text { - Advocating for the importance of equitable programs and } \\
\text { services that support all students' needs and learning profiles }\end{array}$ & \\
\hline & $\begin{array}{l}\text { - Integrating Indigenous histories, cultures, traditions, } \\
\text { worldview, governance, and pedagogies }\end{array}$ & \\
\hline \multirow{6}{*}{$\begin{array}{l}\text { Special } \\
\text { Education, } \\
\text { Specialist } \\
\text { Additional } \\
\text { Qualification } \\
\text { Course } \\
\text { Guideline }\end{array}$} & $\begin{array}{l}\text { Fostering shared leadership in critically exploring, developing, } \\
\text { and implementing programs that respond to students' lived } \\
\text { experiences, development, strengths, interests, and needs }\end{array}$ & 6,917 \\
\hline & $\begin{array}{l}\text { Facilitating leadership practices and innovation in integrating } \\
\text { culturally responsive pedagogy within program planning and } \\
\text { development }\end{array}$ & \\
\hline & $\begin{array}{l}\text { - Fostering an ethical culture that collectively addresses } \\
\text { biases, discrimination, and systemic barriers in order to } \\
\text { support student learning, well-being, and inclusion }\end{array}$ & \\
\hline & $\begin{array}{l}\text { - Fostering a culture of collaboration with interdisciplinary teams } \\
\text { to support student learning, self-advocacy, and transitions }\end{array}$ & \\
\hline & $\begin{array}{l}\text { - Facilitating processes that include parents in the program } \\
\text { planning, development and implementation }\end{array}$ & \\
\hline & $\begin{array}{l}\text { - Facilitating and sustaining inclusive, equitable, accepting } \\
\text { and safe learning communities }\end{array}$ & \\
\hline \multirow{3}{*}{$\begin{array}{l}\text { Inclusive } \\
\text { Classroom } \\
\text { Additional } \\
\text { Qualification } \\
\text { Leadership } \\
\text { Course } \\
\text { Guideline }\end{array}$} & $\begin{array}{l}\text { Advancing a culture of critical inquiry that collectively examines } \\
\text { assumptions, beliefs, and understandings associated with } \\
\text { teaching and learning within the context of this Additional } \\
\text { Qualification }\end{array}$ & 101 \\
\hline & $\begin{array}{l}\text { Fostering an ethical culture that engages in critical reflection } \\
\text { regarding the dimensions associated with creating and } \\
\text { sustaining safe, inclusive, equitable, accepting, and engaging } \\
\text { learning environments }\end{array}$ & \\
\hline & $\begin{array}{l}\text { Promoting a culture of critical inquiry that examines the } \\
\text { significance of relevant legislation including the Ontario Human } \\
\text { Rights Code, the Canadian Charter of Rights and Freedoms, } \\
\text { Safe Schools Act, Accepting Schools Act, Municipal Freedom of } \\
\text { Information and Protection of Privacy Act (MFIPPA), the } \\
\text { Accessibility for Ontarians with Disabilities Act (AODA), and } \\
\text { associated responsibilities of professional practices }\end{array}$ & \\
\hline
\end{tabular}




\section{Discussion}

The very engaged participation at the day-long conference at the University of British Columbia on June 1, 2019, demonstrated that the study of intersectionalities in leadership for supporting inclusive education requires great consideration. Many themes emerged through the summary of the conference coordinator, who collated the copious field notes of each table facilitator and analyzed them for recurring themes. In addition to sharing with the whole group, each table made sure their notes captured the essence of their discussions on the different topics. In these table group discussions and throughout the day, participants raised issues pertaining to otherness, privilege, collaborative communities, inclusion-minded teachers, and the use of case studies to approach students holistically. Even though the event focused mainly on how school administrators could support the inclusion of students with special education needs, it was also clear that the conference highlighted the need for more targeted professional learning for all education staff using case study as a more appropriate method to approach the intersectional aspects of inclusive education.

Knowing that school leadership plays a major role in setting the tone in schools and that school principals' behaviours affect the behaviours of other school staff, the school culture, as well as the delivery of service in the school (Cobb, 2015; Sider et al., 2017), it is important to focus the discussions on intersectionalities in inclusive leadership practices. At the same time some peripheral questions need to be addressed in order for school administrators to be able to pay the required attention to the most intersectional issues they face in their schools including special education needs, gender identity issues, mental health issues, race, and religious issues.

During the conference, participants raised many questions around many other peripheral aspects including work intensification and wellness of school administrators that need to be part of the conversation on inclusive leadership. They also discussed the need for more socio-emotional learning opportunities for principals and vice-principals and the extent to which these leaders understand inclusive education in practice. Nontraditional forms of professional learning (using case studies, making use of coaching, having critical friends, etc.) were suggested as effective ways to support school leaders who dare to engage in socially just and anti-oppressive inclusive educational practices. Some key questions, however, remain. What are some other peripheral aspects that need to be attended to in order for school leaders to work with a fulsome vision of emancipatory inclusive education? Whose responsibility is it to address collateral issues related to these peripheral aspects?

Written feedback received from leadership courses, initial teacher education programs, and school boards that have used the case resource (Sider et al., 2018) to support ongoing learning related to inclusive leadership practices, intersectionality, and anti-oppressive practices have revealed the power of case inquiry to inform professional knowledge, change practices and policies, and challenge beliefs and assumptions. This feedback, which was gained from multiple educational contexts, illuminates the power of the case resource to influence practice and policy. 


\section{Conclusion}

It is not enough to argue that case studies have "a rich, strong history as an effective, engaging, student-centred instructional strategy to supplement more traditional approaches to knowledge transmission" (Maich, 2015, p. xiv). There are still several educators who think of case studies as fiction. More professional learning and more knowledge mobilization are needed to help teachers, parents, learning communities, and school administrators to be more aware of and to address complex intersectional issues.

The quest for knowledge to advance the leadership development of teacher leaders and school administrators related to inclusive education was a key focus leading to the June 1, 2019, conference at the University of British Columbia. Most of the scholars involved in the research project are also currently involved in initial teacher education, continuing teacher education, and the professional learning of school leaders. While they are all convinced of the value of cases in approaching intersectional aspects of complex inclusive education issues, they are also aware that more needs to be done in terms of knowledge mobilization and professional learning (Maich et al. (2020 [this issue]; Porter \& Smith, 2011) to bring other scholars, Indigenous educators, school system administrators, representatives of government ministries, and professional education associations together more often to consider how they can collaboratively work to support students, teachers, and school leaders' well-being, as well as more inclusive practices.

\section{References}

Apple, M. W. (2013). Can education change society? New York, NY: Routledge.

Archibald, J. (2008). Indigenous storywork: Educating the heart, mind, body and spirit. Vancouver, BC: University of British Columbia Press.

Barnes, L. B., Christensen, C. R., \& Hansen, A. J. (1994). Teaching and the case method: Text, cases, and readings. Boston, MA: Harvard Business School Press.

Barroso, C., \& Abreu, W. (2015). Developing ethical thinking in clinical settings: A case study. Procedia-Social and Behavioural Sciences, 171, 661-667. doi:10.1016/j.sbspro.2015.01.175

Battiste, M. (2013). Decolonizing education: Nourishing the learning spirit. Saskatoon, SK: Purich Publishing.

Branson, C. M., \& Gross, S. J. (2014). Handbook of ethical educational leadership. New York, NY: Routledge.

Brock University. (n.d.). Knowledge mobilization [Web page]. Retrieved from https://brocku.ca /lifespan-development-research/knowledge-mobilization/

Calder Stegemann, K., \& AuCoin, A. (2017). Inclusive education: Stories of success and hope in Canadian context. Toronto, ON: Pearson Canada.

Cobb, C. (2015). Principals play many parts: A review of research on school principals as special education leaders 2001-2011. International Journal of Inclusive Education, 19(3), 213-234.

Collins, P. H. (2015). Intersectionality's definitional dilemmas. Annual Review of Sociology, 41, 1-20. doi:10.1146/annurev-soc-073014-112142

Darder, A. (2014). Freire and education. New York, NY: Routledge. 
Davis, C., \& Wilcock, E. (2003). Teaching materials using case studies (C. Baillie, Series Ed.). The UK Centre for Materials Education. Retrieved from http://www.materials.ac.uk/guides/1casestudies.pdf (Now available at www.archive.org)

Denzin, N. K., Lincoln, Y. S., \& Smith, L. T. (Eds.). (2008). Handbook of critical and Indigenous methodologies. London, UK: SAGE Publications.

Foran, J. (2001). The case method and the interactive classroom. Thought and Action, 17(1), 41-50. Retrieved from http://www.nea.org/assets/img/PubThoughtAndAction/TAA_01Sum_05.pdf

Fossey, R., \& Crow, G. M. (2011). The elements of a good case. Journal of Cases in Educational Leadership, 14(3), 4-10. doi:10.1177/1555458911426467

Freire, P. (1970). Pedagogy of the oppressed. New York, NY: Herder and Herder.

Garcia, S. B., \& Ortiz, A. A. (2013). Intersectionality as a framework for transformative research in special education. Multiple Voices for Ethnically Diverse Exceptional Learners, 13(2), 32-47.

Gardiner, M. E., \& Tenuto, P. L. (2015). Reflections of practicing school principals on ethical leadership and decision-making: Confronting social injustice. The Journal of Values-Based Leadership, 8(2). Retrieved from https://scholar.valpo.edu/cgi/viewcontent.cgi?article=1127 \&context $=\mathrm{jvbl}$

Giroux, H. (1992). Border crossings: Cultural workers and the politics of education. New York, NY: Routledge.

Griffiths D., \& Ryan, J. (2018). Case studies for inclusive educators and leaders. Burlington, ON: Word and Deed Publishing.

Goldblatt, P. F., \& Smith, D. (2004). Illuminating and facilitating professional knowledge through casework. European Journal of Teacher Education, 27(3), 334-354.

Goldblatt, P. F., \& Smith, D. (Eds.). (2005). Cases for teacher development: Preparing for the classroom. Thousand Oaks, CA: Sage Publications.

Gonzalez, A. O., \& Collins, P. H. (2019). Interview with Patricia Hill Collins on critical thinking, intersectionality and educational: Key objectives for critical articulation on inclusive education. Journal for Critical Education Policy Studies, (17)2, 151-170. Retrieved from http://www.jceps.com/archives/6434

Hackney, R., McMaster, T., \& Harris, A. (2003). Using cases as a teaching tool in IS education. Journal of Information Systems Education, 14(3), 229-234.

Hanhimäki, E., \& Tirri, K. (2009). Education for ethically sensitive teaching in critical incidents at school. Journal of Education for Teaching, 35(2), 107-121. doi:10.1080/02607470902770880

hooks, b. (1994). Teaching to transgress: Education as the practice of freedom. New York, NY: Routledge.

hooks, b. (2004). Teaching community: A pedagogy of hope. New York, NY: Routledge.

Kincheloe, J. L. (2008). Critical pedagogy primer (2nd ed.). New York, NY: Peter Lang.

Maich, K. (2015). Early learners in preschools and kindergartens: 50 case stories in child development, inclusion, collaboration and special needs. Toronto, ON: Pearson Canada.

Maich, K., \& Hill, R. (2017). Special education case studies: For Ontario classrooms. Toronto, ON: Oxford University Press.

McLaren, P. (1998). Life in schools: An introduction to critical pedagogy in the foundations of education (3rd ed.). New York, NY: Longman.

Mezirow, J., \& Taylor, E. W. (2009). Transformative learning in practice: Insights from community, workplace, and higher education. San Francisco, CA: Jossey-Bass. 
Ontario Education Research Panel. (n.d.). Knowledge mobilization: An OERP perspective. Retrieved from https://arc.thelearningexchange.ca/wp-content/uploads/2018/02/KMB_anOERP-perspective.pdf

Parker, D. C., Smith, D., \& Goldblatt, P. (2009). Teacher education partnerships: Integration of case studies within an initial teacher education program. Brock Education, 18(2), 96-113. Retrieved from https://journals.library.brocku.ca/brocked/index.php/home/issue/view/18

Porter, G., \& Smith, D. (Eds.). (2011). Exploring inclusive education practices through professional inquiry. Rotterdam, The Netherlands: Sense Publishers.

Shulman, J. H. (Ed.). (1992). Case methods in teacher education. New York, NY: Teachers College Press.

Shulman, J. H., \& Colber, J. A. (Eds.). (1988). The intern teacher casebook. San Francisco, CA: WestEd.

Shulman, J. H., Whittaker, A., \& Lew, M. (2002). Using assessments to teach for understanding: A casebook for educators. New York, NY: Teachers College Press.

Sider, S., Maich, K., \& Morvan, J. (2017). School principals and students with special education needs: Leading inclusive schools. Canadian Journal of Education, 40(2). Retrieved from http://journals.sfu.ca/cje/index.php/cje-rce/article/view/2417/2433.

Sider, S., Maich, K., Morvan, J., Specht, J. \& Smith, D. (2018). Exploring leadership practices through case inquiry: Supporting inclusive schools. Toronto, ON: Ontario College of Teachers. Retrieved from https://www.oct.ca/-/media/PDF/Exploring Leadership Practices through Case Inquiry/ExplLdrshpPrctcsCseInqry_en_web.pdf

Simplican, S. C., Leader, G., Kosciulek, J., \& Leahy, M. (2015). Defining social inclusion of people with intellectual and developmental disabilities: An ecological model of social networks and community participation. Research in Developmental Disabilities, 38, 18-29. doi:10.1016/j.ridd.2014.10.008

Smith, D. (2015a). Exploring inter-professional collaboration and ethical practice: A story of emancipatory professional learning. Reflective Practice: International and Multidisciplinary Perspectives, 16(5), 652-676. doi:10.1080/14623943.2015.1071246

Smith, D. (2015b). Exploring leadership development with supervisory officers through case inquiry. Reflective Practice, 16(4), 559-574.

Smith, D., \& Goldblatt, P. F. (Eds.). (2009). Exploring leadership and ethical practice through professional inquiry. Québec City, QC: Les Presses de l'Université Laval.

Smith, D., Kelly, D., \& Allard, C. (2016). Dialogic spaces: A critical policy development perspective of educational leadership qualifications. International Journal of Leadership in Education, 20(4), pp. 393-415. doi:10.1080/13603124.2015.1116608

Smith, L. T. (1999). Decolonizing methodologies: Research and Indigenous peoples. London, UK: Zed Books Ltd.

Stanford University. (1994). Teaching with case studies. Speaking of Teaching, 5(2), 1-4. Retrieved from https://stanford.box.com/public/static/nc91jzcwtu4j2g4xjfc5.pdf

Starratt, R. J. (2004). Ethical leadership. San Francisco, CA: Jossey-Bass.

Starratt, R. J. (2009). Foreword. In D. Smith \& P. Goldblatt (Eds.), Exploring leadership and ethical practice through professional inquiry (pp. xvii-xix). Québec City, QC: Les Presses de l'Université Laval. 
Watson, C. (2014). Effective professional learning communities? The possibilities for teachers as agents of change in schools. British Educational Research Journal, 40(1), 18-29. doi:10.1002/berj.3025

Wettlaufer, J., \& Sider, S. (2019). The importance of trust in school improvement professional learning communities. Journal of Cases in Educational Leadership 22(2), 3-14.

Yamamoto, J. K., Gardiner, M. E., \& Tenuto, P. L. (2013). Emotion in leadership: Secondary school administrators' perceptions of critical incidents. Educational Management Administration \& Leadership, 42(2), 165-183. doi:10:1177/1741143213499260

\section{Authors' Note}

Correspondence concerning this article should be addressed to Jhonel Morvan, Brock University, Jhonel.Morvan@brocku.ca or Déirdre Smith, Ontario College of Teachers, dsmith@oct.ca 